\title{
Inflectional Markers of Mandarese Language in Generative Morphological Perspective
}

\author{
Jerniati I*, Musayyedah, Ratnawati, Andi Indah Yulianti, Hasina Fajrin R \\ Balai Bahasa Provinsi Sulawesi Selatan \\ Makasar, Indonesia \\ *jernihatiku@gmail.com
}

\begin{abstract}
This study investigates inflectional markers of Mandarese language concerning generative morphology. It aims to describe the forms of the inflectional marker and its distribution in the Mandarese language. It deploys a generative morphological approach to analyse language based on linguistic knowledge or intuition of native speakers. It uses the descriptive qualitative method systematically, factually, and accurately describing language facts. It also uses the library research method and linguistic field method to obtain the data. The library research method used is to obtain basic concepts or relevant theories to the problem investigated (inflection of Mandarese language). Besides, the linguistic field method carried out is collecting the data in the location. Data collection techniques are elicitation, recording, note-taking, and documentation. Spoken data are obtained from native speakers, while written data are Mandarese folklores, magazines, and relevant studies. The result shows that there are three forms of the inflectional marker in Mandarese language, including inflectional affix with a repetitive marker $(-i$ and -boi), inflectional affix with a comparative marker (si-), and inflectional affix with clitic marker in terms of completive aspect markers (mi, -maq, -moq), incomplete aspect markers (-pa, -paq, -pao, -pi), and continuative aspect markers (-dua, -duaq, -duao, -duai). The distribution of inflectional markers in Mandarese language generally has no impact on word class changes, and all widely distribute. In the morphological word formation, the inflectional marker forms tend to be located outside or far from the root.
\end{abstract}

Keywords-markers, inflection, Mandarese language, generative morphology

\section{INTRODUCTION}

The number of languages in Indonesia, identified by Badan Pengembangan dan Pembinaan Bahasa [1], is 718. It places Indonesia in the second position of other countries having various local languages. Consequently, the efforts are carried out using and representing these languages as research objects and preserving and developing them. According to Ethnologue [2], one of the threatened languages in Indonesia is the Mandarese language. Indeed, of local languages in West Sulawesi, the Mandarese language is widely used.

Factors affecting the vitality of the Mandarese language include globalization and migration. The borderless flow of information makes it easy for people to connect to affect many aspects of human life, one of which is language. The expansion of West Sulawesi Province attracts outsiders so that the natives and migrants mingle altogether. This condition causes the language used as a means of communication among them is mostly the Indonesian language. Therefore, efforts in preventing the Mandarese Language from being threatened with extinction need to be done. Considering such condition, Mandarese language developments and research targets included phonology, morphology, syntax, semantic, discourse, and others are necessary.

Studies on the morphology, especially morphological aspects, have been conducted by Palenkahu [3] on Mandarese language structure, Muthalib [4] on Mandarese grammar, and Badulu [5] on the morphological system of verbs in Mandarese language. They generally discussed morphological elements in brief. According to Palenkahu [3] and Muthalib [4], the Mandarese language has some affixes. Besides, Badulu [5] portrays the morphological system in Mandarese language, particularly verbs.

Generative morphology is a language analysis based on linguistic knowledge or intuition of native speakers. It is also a system of rules which consists of a limited set of rules [5]. It indicates that the study can produce acceptable and standardized derivations. Meanwhile, inflection and derivations as the word-formation system are parts of the morphological analysis. Functional morphemes, both bound (inflectional) and free morphemes (e.g., articles, auxiliaries), carry grammatical meanings that radically change the overall interpretation of a sentence and discourse [6]. Besides, no sentence meaning is complete without taking the functional and especially the inflectional morphology contributions.

Subroto [7] states that inflation and derivation always distinguish in the description of Indo-European languages. The reason caused by those languages' classification is inflection. It is different from Indonesian and the Indonesian archipelago, classified not as inflected, however, by understanding the concepts of inflection and derivation, which are increasingly sharpened by linguists in the latest literature, such as Scalise [8], Aronoff [9], Bauer [10], and Verhaar [11]. The author 
hopes to utilize these concepts to sharpen the analysis of the morphology of the Mandarese language.

Bauer [10] suggests that inflection morphology and derivation morphology are:

"Affixes can be of two types inflectional or derivational. An inflectional affix is one that produces a new word-form of a lexeme from a base. A derivational affix is one that produces a new lexeme from a base. Take a word-form like re-creates. It can be analysed into a prefix, making a new lexeme recreate from the base creature. However, the suffix-s provides another word-form of the Lexeme recreate. The prefix is derivational, but the suffix $-\mathrm{s}$ is inflectional."

In line with Bauer, Yule [12] differentiates the affixes of derivation from inflection. Derivation affixes used in derivation are derivative, while inflection affixes used in affection are inflected. Scalise [8] and Aronoff [9] argue that Infection is not related to new word formation, while derivation concerns the formation of new word-formation. Ermanto [13] concludes that one of the differences between the inflection process and the derivation process is that inflection produces word-forms from a lexeme and the derivation produces a lexeme. Based on the sharpening of these two concepts and this paper's title, the author focuses on one concept: inflected morphology.

Bickford and Daly [14] explain that inflectional morphology is a morphemic process without changing a word into another word and never changing the syntactic category but producing other forms of a similar word. It implies that this process does not change the word class. In line with Cook [15], in Syamsudduha [16], it suggests that the inflection is a relational marker, adjusting one of the main word classes used in syntax without changing its word class. Additionally, Samsuri [17] states that inflection occupies a similar distribution with its base.

Van der Spuy [18] explains that a morpheme only becomes meaningful if embedded in a larger, word-level schema, either abstract or concrete (with actual phonetic representation). Also, the inflection is a morphemic changing process that maintains the linguistic identity of its related word.

The flectional or inflectional group are a paradigmatic list, consisting of forms from a similar word. Both similar and different words are related to word identities or lexical identities. For example, roof and roof have a similar lexical identity. De Belder [19] says that a derivation typically consists of a functional structure merged on top of a root. As a result, roots are rarely attested in the absence of functional projections.

The difference between singular and plural is only a flectional difference [11]. It is similar to menjual and dijual (Indonesian language). The derived words are similar jual, in which menjual is an active verb while dijual is a passive verb. The difference between active and passive is the inflectional difference. Explanation about singular and plural comes from Hayes et al. [20]. Hayes has argued that one internal innate constraint-based explanation for the dissociation between regular and irregular plurals in compounds arises from a theory that orders morphological processes on a hierarchy of levels. According to Kiparsky's [21] level ordering model, morphology is generated at three hierarchical stages. At Level 1 , irregular inflections and primary affixes (e.g., ian, -ous, -ion) are applied. At Level 2, derivational affixes (e.g., er, -ism, ness) and nominal compounding are generated, and finally, regular inflection (e.g., ed, -s) is applied at Level 3. Moreover, Kridalaksana [22] adds that the inflection also refers to elements added to a word to show a grammatical relation.

However, inflectional markers as part of word formation in Mandarese language have not generally accounted for inflectional morphological analysis is represented in deep structure trees with inflectional features, while inflection rules describe phonological forms of affixes. Based on the explanation above, this study's main problem is how marker forms indicate the inflection and how inflectional affixes are distributed in the Mandarese language. In general, it can enrich linguistic references on Mandarese language.

\section{AIM OF THE STUDY}

The word-formation process, including inflections, will reveal the grammatical pattern that will contribute to word development. Hence, this study investigates inflectional markers of Mandarese language by applying the Generative Transformation (TG) theory.

\section{METHODS}

The research method employed is the library research method and linguistic field method. The library research method is used to get the basic concept or relevant theory to the problem investigated. The linguistic field method is conducted to obtain the data, both spoken and written, in the location.

Furthermore, the techniques used to collect data are 1) notetaking techniques: these techniques are used to note various forms of affixes and morphemes that play a role in the affixes of Mandar language inflection markers, and 2) retrospect techniques; This technique is used to select all data obtained to obtain accurate data. This technique includes collecting all vocabulary in Mandarese language from several reading materials, classifying the types of inflection markers, classifying words according to word classes, and identifying the meanings.

\section{RESULTS}

Forms of inflection in Mandarese language are divided into three, including 1) inflection with repetitive marker, 2) inflection with comparative marker, 3) inflection with clitic marker. 


\section{A. The marker of $i$ - and -boi}

A repetitive marker is a marker that describes an action conducted repetitively. In Mandarese language, these markers include $-i$ and -boi. These affixes are reflected in example 1 .

$\begin{array}{ll}\begin{array}{l}\text { Example (1) } \\ \text { appas } \\ \text { 'hit' }\end{array} & \text { appassi [ap:as:i] } \\ & \text { V-REP } \\ \text { 'hit repetitively.' } & \text { sapui [sapui] } \\ \text { sapu } & \text { N-REP } \\ & \text { 'wipe repetitively.' } \\ \text { timbei [timbei] } \\ \text { 'thbe } & \text { N-REP } \\ \text { 'throw' } & \text { 'throw repetitively.' } \\ \text { roqdo } & \text { ro?doi [roPdoi] } \\ \text { 'shake } & \text { V-REP } \\ & \text { 'shake repetitively.' }\end{array}$

The affix - $i$ in appassi, seruqi, timbei, and roqdoi functions as a repetitive marker. This marker is always located near the root and cannot be located between other forms or followed by other forms. Besides, affix $-i$ in the verb and noun bases do not cause changes in lexical categories or word classes.

The use of repetitive marker $-i$ in sentences can be seen in the following example 2 .

\section{Example (2)}

Appass-I diting kasoro anna messung kareqamusna

hit- REP that bed so out dust

'Hit that bed repetitively to make the dust-out.'

Roqdo-I botol susunna anakmu annamapaccing.

shake-REP bottle milk your child so clean

'Shake your child's milk bottle repetitively to make it clean.

In the Mandarese language $-i$ is a singular third-person pronoun when linked with a verb; for example, lamba 'to go' + (- i) becomes 'he goes' meaning to do work 'to go.' However, if $-\mathrm{i}$ is linked with an adjective, for example, malolo 'beautiful' becomes 'maloloi', which means "she is beautiful".

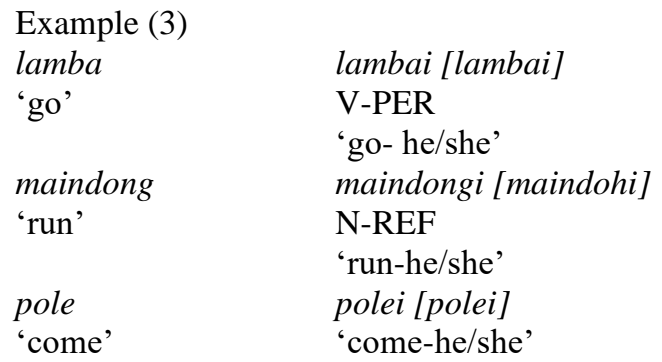

Besides $-i$ marker, there is also a marker in terms of embedded morpheme, that is -boi. It is shown in the following example 4.

\begin{tabular}{|c|c|}
\hline Example (4) & \\
\hline pole & poleboi [poleboi] \\
\hline 'come' & V-REP \\
\hline & 'come again.' \\
\hline meloq & meloqboi [melorboi] \\
\hline "want' & $\begin{array}{l}\text { Adj-REP } \\
\text { 'want again.' }\end{array}$ \\
\hline
\end{tabular}

The affix -boi in poleboi and meloqboi functions as a repetitive marker. Those examples show that the position of boi is nearer the root. The addition of -boi marker also does not cause changes in lexical categories and word classes.

\section{B. The marker of si-}

A comparative marker is a marker representing something (especially adjective) compared. It is shown in terms of affixes as the following example 5 .

$\begin{array}{ll}\begin{array}{l}\text { Example (5) } \\ \text { keccuq } \\ \text { 'small' }\end{array} & \text { sikkeccuq [sik:ec:uP] } \\ & \text { COMPR-Adj } \\ \text { 'as small as.' } & \text { simballeq [simbal:e?] } \\ \text { balleq } & \text { COMPR-Adj } \\ \text { 'wide' } & \text { 'as wide as.' } \\ \text { lotong } & \text { sillotong [sil:otoy] } \\ \text { 'black' } & \text { COMPR-Adj } \\ & \text { 'as black as' }\end{array}$

The comparative marker si- in sikkecuq, simballeq, and sillotong shows that $s i$ - is near the root. The addition of this marker does not change word classes and lexical meaning but gives a little bit changes on grammatical meaning since 'as ... as' meaning is added.

The application of these words in sentences is shown in example 6.

\footnotetext{
Example (6)

Boyanna keccu sikkeccuq boyaqu

House-POS small COMPR-small house-POS

'His house is as small as my house.'

Gayanna i Kaco simballeq bose

Parang-POS Kaco COMPR-wide oar

Kaco's parang is as wide as an oar.'
Biluaqna malotong simmalotong boring. Hair-POS black COMPR-black charcoal
'My hair is as black as charcoal'.

These comparative markers are also found in the more complex forms, as follows. 


$\begin{array}{ll}\text { sikkeccuq } & \text { pasikkeccuq [pasik:ec:u?] } \\ & \text { CAUS-COMPR } \\ & \text { 'to make as small as' } \\ \text { simballeq } & \text { pasimballeq [pasimbal:e] } \\ & \text { CAUS-COMPR } \\ & \text { to make as wide as.' } \\ \text { sillotong } & \text { sillotong [sil:otoy] } \\ & \text { CAUS-COMPR } \\ & \text { to make as black as.' }\end{array}$

The comparative marker $s i$ - in the example above is preceded by causative $p a-$ and diathesis $d i$-. It makes the position of si- near the root. Based on its function, si- is also categorized as an adverb.

Besides, the marker si- can also be linked with a verb; for example, timbe 'throw' becomes sitimbe "throw at each other"

$\begin{array}{ll}\begin{array}{l}\text { Example (7) } \\ \text { ala } \\ \text { 'ambil' }\end{array} & \text { siala [siala] } \\ & \text { RESIPR-V } \\ \text { 'saling ambil' } \\ \text { urung } & \text { siurung [siuruh] } \\ \text { 'lebar' } & \text { RESIPR-V } \\ & \text { 'saling cium' } \\ \text { tinroq } & \text { sitinroq [sitinro?] } \\ \text { 'kejar' } & \text { RESIPR-V } \\ & \text { 'saling kejar' }\end{array}$

\section{Inflection with Clitic Affix}

Clitic is an embedded form that phonologically has no own stresses and cannot be considered an embedded morpheme because it can fill gatra in phrasal or clausal levels. However, it has no characteristics since it is impossible to be applied as a free form.

Inflection with clitic affix in Mandarese language is in aspect form. Aspect is a grammatical category of verbs indicating the duration and kind of action, whether the action starts, finishes, is ongoing, and so forth, as Kridalaksana (2008) stated. In the Mandarese language, there are three aspect markers, as follows.

1) Completive aspect marker: A Completive aspect marker is an aspect describing a finished action. Verbal affixes in terms of completive are shown in the following.

$\begin{array}{ll}\begin{array}{l}\text { Example (8) } \\ \text { polemi }\end{array} & \\ \text { polemaq } & \text { 'have come' } \\ \text { polemoq } & \text { 'y have come.' } \\ \text { polemi } & \text { 'he have come.' } \\ \text { masaemi } & \text { 'have been a long time.' } \\ \text { masaemaq } & \text { 'I have been a long time.' } \\ \text { masaemoqo } & \text { 'you have been a long time.' } \\ \text { masaemi } & \text { 'he has been a long time.' }\end{array}$

Completive aspect marker -maq, -moq, and -mi are added to the base verb pole 'come' and base adjective masae 'long time' to become polemaq, polemoq, polemi, and masaemaq, masaemoq, masaemi. It indicates that these completive markers are near to the stem or root. Moreover, these markers are unable to be located between derivational affixes or followed by derivational affixes. Besides, adding these markers does not cause the lexical category and word-class changes. Hence, the affixes with completive aspect marker are categorized as the inflection with aspect marker affixes.

The use of completive aspect markers in sentences are reflected in the following.

Example (9)

Polemaq di Makka anna mendaiq dallequ.

come have-COMPR to Mecca so increase my income

'I have come to Mecca, so my income increases.'

Masaemi lamba sumobal muanena.

long time-COMPR go shipping husband-POS

'It has been a long time since her husband went shipping.'

Polemi di galung kamaqu.

come-have-COMPR to rice field my father

'My father has come to the rice field.'

2) In-completive aspect marker: An in-completive aspect is an aspect reflecting an undone action. Verbal affixes in terms of in-completive are the following.

Example (10)
lambapai
lambapaq
lambapao
lambapai
masannangpai
masannangpaq
masannangpao
masannangpai

'later if have gone.'

'later if I have gone.'

'later if you have gone.'

'later if he has gone.'

'later if have been calm.'

'later if I have been calm.'

'later if you have been calm.'

'later if he has been calm.'

Incompletive aspect markers -paq, -pao, and -pai, are added into verb lamba 'go' to become lambapai, lambapaq, lambapao, and lambapai. They are also added into base adjective masannang 'calm' to be masannangpai, masannangpaq, masannangpao, and masannangpai. The addition of these affixes does not make any changes, both lexical categories, and word classes. Besides, they are located near the stem or root so that derivational affixes cannot separate them. However, at the phrasal level, they are possibly located between other forms. For example, lamba togappaq refers to 'later, if I have already gone.'

The use of incompletive aspect markers in sentences is shown in example 11.

Example (11)

Lambapao naung di Mandar namane meccoeaq. 'go-INCOMP to Mandar then join-POS"

Masannangpai lembong mane meakkeqo sau di sasiq. 'calm-INCOMP wave then go-POS to sea' 
3) Continuative aspect marker: Continuative aspect marker is an aspect describing continuous action. Verbal affixes reflected continuative are the followings.

$\begin{array}{ll}\text { Example (12) } & \\ \text { meapidua } & \text { 'be cooking.' } \\ \text { meapiduaq } & \text { 'I am cooking.' } \\ \text { meapiduao } & \text { 'you are cooking.' } \\ \text { meapiduai } & \text { 'he is cooking.' } \\ \text { makappaqdua } & \text { 'still strong.' } \\ \text { makappaqduaq } & \text { 'I am still strong.' } \\ \text { makappaqduao } & \text { 'you are still strong.' } \\ \text { makappaqduai } & \text { he is still strong.' }\end{array}$

Continuative aspect markers -duaq, -duao, and -duai are added into verb meapi 'cook' to be meapiduaq, meapiduao, and meapiduai. If they are added to the adjective makkapaq 'strong', they become makappaqduaq, makappaqduao, and makappaqduai. Adding these markers does not change word classes. Besides, these inflectional forms are always located near the stem or root. They cannot be between other forms or followed by other forms, except at the phrasal level. For example, matindo nasangduai indicates 'they are all sleeping.' The use of continuative aspect markers in sentences is indicated as the following.

\section{Example (13) \\ Andiangaq mala mating meapiduaq. \\ No-POS able to there cook-CONT \\ 'I am not able to go there; I am cooking.' \\ Makappaqduai sitteng wattunna naqimuane. \\ Strong-CONT same its time youth \\ 'He is still strong as when he was young.'} table 1.

These three aspect markers are represented in the following

TABLE I. ASPECT MAKERS

\begin{tabular}{|l|l|l|l|}
\hline Neutral & Completive & Incompletive & Continuative \\
\hline Neutral & $-m i$ & $-p a$ & Dua \\
\hline $\mathrm{P}_{1}$ & $-m a q$ & $-p a g$ & $-d u a q$ \\
\hline $\mathrm{P}_{2}$ & $-m o q$ & $-p a o$ & $-d u o$ \\
\hline $\mathrm{P}_{3}$ & $-m i$ & $-p i$ & $-d u a i$ \\
\hline
\end{tabular}

The schema in Table 1 illustrated the markers implying neutral meaning generally in three aspects, they are (-mi, - $p a$, $d u a$ ), neutral $\mathrm{P}_{1}$ (pronoun 1) is -maq, -paq, and duaq, neutral $\mathrm{P}_{2}$ ( $2^{\text {nd }}$ pronoun) is $m o q,-p a o,-d u a o$, neutral $\mathrm{P}_{3}$ ( $3^{\text {rd }}$ pronoun) is $m i$, -pi, and duai. Furthermore, the marker of completive aspects implies completive action is -mi, -maq, -moq, and -mi, incompletive aspect implies incompletive action, $-p a$, $-p a q$, $p a o$, and $-p i$, and continuative aspect implies the action or condition that is still happening, such as: -dua, -duaq, -duao, and -duai.
Based on the inflection forms analysis, it is proven that they are located far from the root or on the outside. It occurs once other derivational forms are embedded into the same base form. The inflection forms are also located inside or near the root, but the following affixes are not derivational.

D. Inflectional Rules

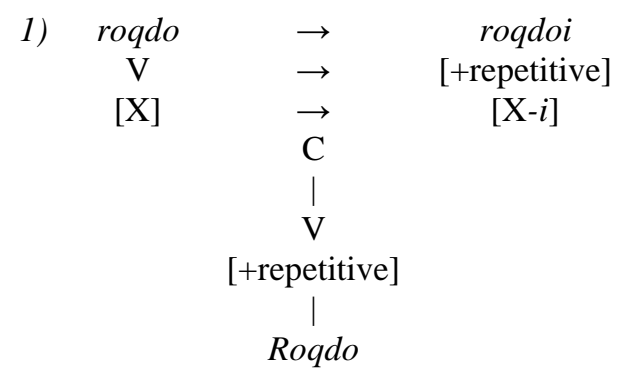

$\begin{array}{ccc}\text { 2) issang } & \rightarrow & \text { muissang } \\ \mathrm{V} & \rightarrow & {[+\mathrm{P} 2 \text { tg] }]} \\ {[\mathrm{X}]} & \overrightarrow{\mathrm{C}} & {[\text { mu-X] }} \\ & \stackrel{\mathrm{V}}{\mathrm{V}} & \\ & {[+\mathrm{P} 2 \mathrm{tg}]} & \\ & \text { Issang } & \end{array}$

$\begin{array}{ccc}\text { meloq } & \rightarrow & \text { meloaq } \\ \mathrm{V} & \rightarrow & {[+\mathrm{P} 1 \mathrm{tg}]} \\ {[\mathrm{X}]} & \overrightarrow{\mathrm{C}} & {[\mathrm{X}-\mathrm{aq}]} \\ & \mathrm{C} & \\ & \mathrm{V} & \\ & {[+\mathrm{P} 1 \mathrm{tg}]} & \\ & \mid & \\ & \text { Meloq } & \end{array}$
4) boyang $\rightarrow \quad$ boyanna
$\mathrm{N} \quad \rightarrow \quad[+\mathrm{P} 3 \operatorname{tg}]$
$[+\mathrm{POS}]$

$[\mathrm{X}] \quad \rightarrow \quad[\mathrm{X}-n a]$

$\mathrm{C}$

N

[+P3tg]

[+POS]<smiles>C=C</smiles>

Boyang 
5)

\begin{tabular}{|c|c|}
\hline pole & $\rightarrow$ \\
\hline $\mathrm{V}$ & $\rightarrow$ \\
\hline$[\mathrm{X}]$ & $\vec{a}$ \\
\hline & C \\
\hline & $\mathrm{V}$ \\
\hline & {$[+\mathrm{P} 1 \mathrm{tg}]$} \\
\hline & $\begin{array}{c}{[+ \text { have }]} \\
\mid \\
\text { polemaq }\end{array}$ \\
\hline
\end{tabular}

6)

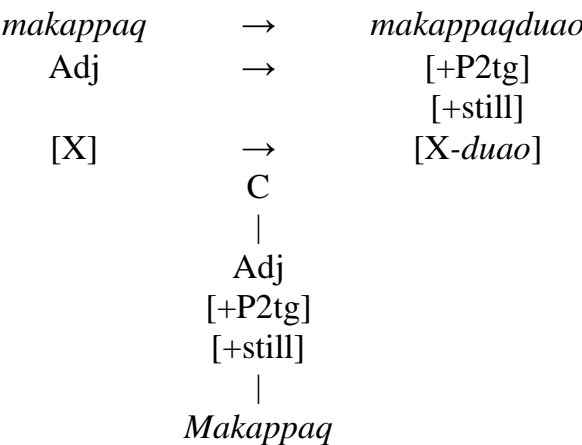

\section{E. Distribution of Inflectional Affixes}

The distribution of inflectional affixes is limited to the possibility of substituting affix by another affix in an inflection formation. It is explained in the following.

Inflectional affixes in terms of repetitive marker consist of $i$ and $-b o i$. The distribution of $-i$ is embedded into verbs and nouns, and it widely distributes. Likewise, the marker -boi is possibly embedded into verbs and adjectives and widely distributes.

Inflectional affix in terms of comparative marker includes si. Its distribution reflected is sikkarambo 'as far as,' simmalolo 'as beautiful as,' and simmammis 'as sweet as.' It shows that inflectional affix $s i$ - is embedded in adjectives and widely distributes.

Furthermore, inflectional markers in terms of completive aspect markers (-mi, - am, -maq, -moq) are indicated in some words, such as malaimi 'have gone home,' masaemi 'have been a long time,' malaimaq 'I have gone home,' masaemaq 'I have been a long time,' malaimoq 'you have gone home,' and masaemoq 'you have been a long time.' These affixes' distribution shows that the completive marker as inflectional affixes is embedded into verbs and adjectives and widely distributes.

Inflectional affixes in terms of incompletive aspect markers (-pa, -paq, -pao, and -pi) are represented in polepa 'later if have come,' massaupa 'later if I have been well,' polepao 'later if you have come,' massaupao 'later if you have been well,' polepai 'later if he has come,' and massaupai 'later if he has been well.' These affixes' distribution indicates that the inclompetive marker as inflectional affixes is embedded into verbs and adjectives and widely distributes.

Inflectional affixes in terms of continuative aspect markers (-dua, -duaq, -duao, -duai) are shown in massasadua 'be washing,' malolodua 'still beautiful,' massasaduaq 'I am washing,' maloloduaq 'I am still beautiful,' massassaduao 'you are washing,' maloloduao 'you are still beautiful,' and massassaduai 'he is washing.' These affixes' distribution shows that the continuative marker as inflectional affixes is embedded into verbs and adjectives, and it widely distributes.

\section{CONCLUSIONS}

The forms of inflection in Mandarese language are indicated in three affixes, including inflectional affix with a repetitive marker $-i$ and $-b o i$, inflectional affix with comparative marker $s i$-and inflectional affix with clitic marker in terms of aspect markers (completive: -mi, -am, -maq, -moq, incompletive: - $p a,-p a q,-p a o,-p i$, and continuative: -dua, duaq, -duao, duai). In general, these affixes do not give changes in word classes and all widely distribute. The wordformation of inflectional forms tends to be on the outside or far from the root.

\section{REFERENCES}

[1] KEMENDIKBUD, Bahasa dan Peta Bahasa di Indonesia, 2020. [Online] Retrived from: https://petabahasa.kemdikbud.go.id/.

[2] SIL International, Mandar, Ethnologue: Languages of the World. [Online] Retrieved from: https://www.ethnologue.com/language/mdr.

[3] R.A. Pelenkahu, A. Muthalib, and M.Z. Sangi, Struktur Bahasa Mandar. Pusat Pembinaan dan Pengembangan Bahasa. Jakarta: Departemen Pendidikan dan Kebudayaan, 1983.

[4] A. Muthalib, Tata Bahasa Mandar. Jakarta: Pusat Pembinaan dan Pengembangan Bahasa, 1992

[5] A.M. Badulu, Sistem Morfologi Kata Kerja Bahasa Mandar. Jakarta: Pusat Pembinaan dan Pengembangan Bahasa, Departemen Pendidikan dan Kebudayaan, 1985.

[6] R. Slabakova, "Inflectional Morphology," in The Handbook of Advanced Proficiency in Second Language Acquisition, P. A. Malovrh and A. G. Benati, Eds. Amerika: John Wiley \& Sons, Inc, 2018.

[7] E. Subroto, Pengantar Metode Penelitian Linguistik Struktural. Surakarta: Sebelas Maret University Press, 1992.

[8] S. Scalise, Generative Morphology. Dorrech-Hallad: Foris Publications, 1992.

[9] Aronoff and Fudeman, What is Morphology. Oxford: Blackwell Publishing, 2005.

[10] L. Bauer, Introduction Linguistic Morphology. Edinburgh: Edinburgh University Press, 1988.

[11] J.W. . Verhaar, Pengantar Linguistik. Yogyakarta: Gadjah Mada University Press, 1996.

[12] G. Yule, The Study of Language. Cambridge: Cambridge University Press, 1996

[13] Ermanto, "Proses Morfologi Infleksi pada Adjektiva Bahasa Indonesia," J. Hum., vol. 15, no. 1, pp. 41--52, 2016.

[14] J.A. Bickford and J. Daly, A Course in Basic Gramatical Analysis. Tucson: Summer Institute of Linguistics, 1995.

[15] W.A. Cook, Introduction to Tagmemic Analysis. Toronto: Halt, Rinehart, and Winston, 1969. 
[16] Syamsudduha, "Sistem Derivasi dan Infleksi Bahasa Bugis," Hasanuddin University, 1999.

[17] Samsuri, Analisis Bahasa. Jakarta: Erlangga, 2004.

[18] A. Van der Spuy, "Construction Morphology and Inflection,” Lingua, p. 2017, 12AD.

[19] M. De Belder, "The Root and Nothing but the Root: Primary Compounds in Dutch," Syntax, vol. 20, no. 2, pp. 138-169, 2017, doi: $10.1111 /$ synt. 12133 .
[20] J.A. Hayes, P.M. Smith, and V.A. Murphy, "Modality effects in compounding with English inflectional morphology," Br. J. Psychol., vol. 96, no. 3, pp. 295-311, 2005, doi: 10.1348/000712605X48962.

[21] P. Kiparsky, "From Cyclic Phonology to Lexical Phonology," in The Structure of Phonological Representations, In H. van der Hulst \& N. Smith, Ed. Dordrecht: Foris Publications, 1983, pp. 131--175.

[22] H. Kridalaksana, Kamus Linguistik Edisi Keempat. Jakarta: Gramedia Pustaka Utama, 2008. 